\title{
Clinical predictors of cardiac autonomic neuropathy in patients with type 1 diabetes
}

\author{
Cinthia Minatel Riguetto ${ }^{*}$, Caroline Rigoleto Takano, Maria Cândida Ribeiro Parisi, Elizabeth João Pavin, \\ Arnaldo Moura Neto
}

From 20th Brazilian Diabetes Society Congress

Porto Alegre, Brazil. 11-18 November 2015

\section{Background}

Cardiac autonomic neuropathy (CAN) is frequently underdiagnosed. The prevalence of CAN rises with diabetes duration and poor glycemic control. Individuals with DM and CAN have an increased mortality risk, up to $53 \%$ five yrs. after diagnosis. Early identification can improve treatment, quality of life and mortality.

\section{Objective}

Our aim was to determine the prevalence of CAN in patients with type 1 diabetes (T1D) and its association with clinical characteristics.

\section{Materials and methods}

We evaluated 102 patients with T1D (67\% female) divided in 2 groups: with and without CAN. Mean age and HcA1c were $34,27 \pm 10,96$ yrs. and $9.0 \pm 2.0 \%$, respectively. CAN was assessed by Poly-Spectrum software using standardized cardiovascular reflex testing and measures of heart rate variability. Statistical significance was set at $5 \%$.

\section{Results}

CAN was diagnosed in 39 (38.2\%) patients. No statistically significant differences were found in age $(34.87 \pm 9.71 \mathrm{vs}$. $33.90 \pm 11.74$ yrs.; $\mathrm{p}=0.467)$, age at diagnosis $(15.10 \pm 9.16$ vs. $17.38 \pm 11.29$ yrs.; $\mathrm{p}=0.495)$ and $\mathrm{HbA} 1 \mathrm{c}(9.26 \% \pm 2.04$ vs. $8.84 \% \pm 2.07 ; \mathrm{p}=0.144$ ) between groups. Hypertension and dyslipidemia were seen more frequently in patients with CAN (61.5 vs. $19 \% ; \mathrm{p} \leq 0.001$ and 51.3 vs. $22.2 \%$; $=0.002$, respectively). Patients with CAN had higher total cholesterol $(\mathrm{p}=0.009)$ and triglycerides $(\mathrm{p}=0.004)$. Patients with CAN complained more often of post-prandial sweating

\footnotetext{
* Correspondence: cinthia.mr@hotmail.com

UNICAMP, Campinas, Brazil
}

Figure 1 Clinical predictors of cardiac autonomic neuropathy in patients with type 1 diabetes. Values are shown as frequency (\%) and mean (standard deviation)

and orthostatic hypotension ( 35.9 vs. $14.3 \%$; $=0.011$ and 51.3 vs. $30.2 \%$; $\mathrm{p}=0.033$, respectively). Other symptoms questioned were similar between groups, including 
hypoglycemia ( $\mathrm{p}=0.7)$. CAN showed a rising prevalence as complication severity increased. For retinopathy, the frequency of CAN was $54.2 \%, 60 \%, 75 \%$ and $80 \%$ in those with nonproliferative, proliferative, unilateral and bilateral blindness, respectively $(\mathrm{p}<0.001)$. Regarding nephropathy, CAN was present in $41.2 \%, 75 \%, 88.9 \%, 100 \%$ and $100 \%$ in patients with microalbuminuria, macroalbuminuria, chronic kidney disease, hemodialysis and kidney transplant, respectively $(\mathrm{p}=<0.001)$. Diabetic neuropathy, motor sensory neuropathy/symmetric polyneuropathy and more than one neuropathy were seen in $72 \%$ and $100 \%$ of patients with CAN, respectively $(\mathrm{p}=0.001)$.

\section{Conclusions}

These results support an association of increased CAN prevalence and chronic complications and their severity. CAN was also associated with hypertension and dyslipidemia, but with few autonomic symptoms (post-prandial sweating and orthostatic hypotension). As expected, HbA1c had no relevance in CAN occurrence.

Published: 11 November 2015

doi:10.1186/1758-5996-7-S1-A15

Cite this article as: Riguetto et al:: Clinical predictors of cardiac autonomic neuropathy in patients with type 1 diabetes. Diabetology \&

Metabolic Syndrome 2015 7(Suppl 1):A15.
Submit your next manuscript to BioMed Central and take full advantage of:

- Convenient online submission

- Thorough peer review

- No space constraints or color figure charges

- Immediate publication on acceptance

- Inclusion in PubMed, CAS, Scopus and Google Scholar

- Research which is freely available for redistribution

Submit your manuscript at www.biomedcentral.com/submit
C Biomed Central 